\title{
技術解説
}

\section{欧米諸国の放送事情 $(1)$}

\section{1. ま え がき}

先進諸国の放送事情についての解説書はほとんどな く，また，技術分野を概観したものもないといって差支 えない，ての解説シリーズは，筆者が担当している海外 技術協力業務を通して得られた資料類を参照してまとめ

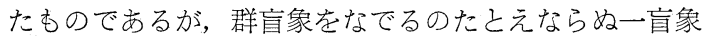
をなでたむのであるから，参照した資料の範囲む限られ ている.

したがって若干の不備な点む, あるいは見られるかむ 知れないが，できる限り各国放送機関の在日駐在員に取 材協力を依頼し，訂正してもらった。しかし技術部門に 関して詳しい駐在員は少なく, バランスの取れた解説と なり得ないととを打断りしておく、また，とのシリーズ は

第 1 回はフランス，スウェーデン

第 2 回はイギリス，イタリー

第3 回はドィッ，オランダ, $\mathrm{EBU}$

第 4 回はカナダ，アメリカ

の4回に分けて，紹介することとしたい．

\section{2. フランスの放送}

フランス放送協会, 旧 ORTF は，1975 年1月 1 日か ら 7 分割され，表 1 に示すように，7部門別事業体に分 かれた．乙れは相次ぐストライキに対処し，放送番組制 作の独立性を保ち，かつ放送を政府の管理の下に置くた めに分離したむので，各事業体を競合させ，かつ受信料 配分委員会が，（1)番組委員会の各事業体の番組に対す る評価，(2) 世論調査による結果，をむとに一定の方程 式を使って受信料を配分する方法をとることになった。

図1にその関係を示す.

7 分割された機関は，表1亿示すとおり国立機関 (Sociéte Nationale) 之有限株式会社 (Sociéte Ansnyme) の 2 種類に分類される.

図 1 の視聴覚技術審議会 (D.I.T.A.V) は, ラジオ，

"Broadcasting Organizations in Western Countries" by Tomiyasu Suenaga (NHK Engineering Head Quarters, Tokyo)
NHK 技術本部末 永富康

テレビ，衛星技術分野を担当する機関の活動の調整を行 うための組織で, 総理府, 外務省, 大蔵省, 工業省, 通 産省，自治省などの代表者で構成されている，特に新技 術，ディジタル衛星，ビデオディスク，テレテキストな ぞが，その対象となる，審議会はまた，技術上のまたは 教育訓練上の問題についてあ関与する義務があり，ての ため公的な視聴覚技術担当機関，特に T. D.F の協力 をうける。

また視聴覚技術普及審議会 (Association pour la diffu一 sion des techniques francaises audiovisuelles) (T.F. T. V) は SECAM カラー技術の国際的な普及のために， 1978 年 1 月 18 日に首相から D. I. T. A. V 飞出された要 請に基づき設けられたすのである. T.F.T.V は図 1 の 各メンバー機関の協力を受けて, 次に示す業務の連絡調 整をする。

（1） フランス視聴覚技術の普及

(2) 国内展示会の開催

（3）視聴覚技術の教育訓練のプログラム作成

（4）海外に打ける展示会の編成

（5） フランス視聴覚技術利用上の問題解決への寄 与

\subsection{T. D. F. (Télédiffusion de France)}

TDF はフランスの放送機関の中心をなす会社で，そ の主要業務は,

（a）テレビおよびラジオの送信業務

（b）テレビおよびラジオの番組の品質監視

（c）放送網の設計，運用，改善および維持管理

(d) テレビ招よびラジオ機器の研究設計, および調 查

（e） C C I R および EBU の参加（代表機関とし て)

などである。したがって，フランスのテレビ，ラジオ放 送網一(回線を含む) の全部を受け持っている. 図 2 に T.D.Fの組織を示す.

(1) 音声放送網（7 系統)

France-Inter: 中波（含長波局 1)，61 局

France-Culture: 中波 $\}$ 送信機 318 台 


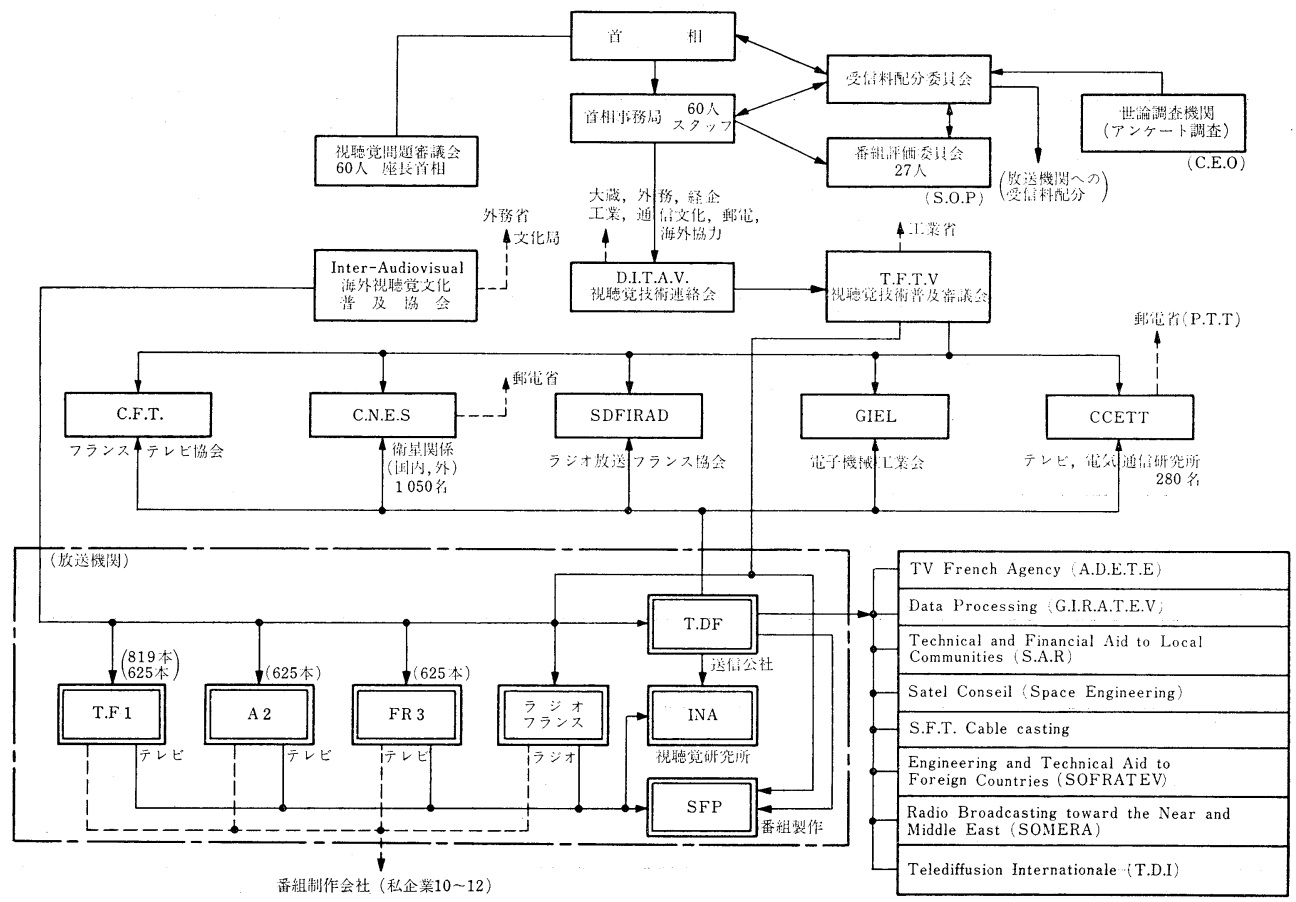

図 1 フランスの放送関連組織図

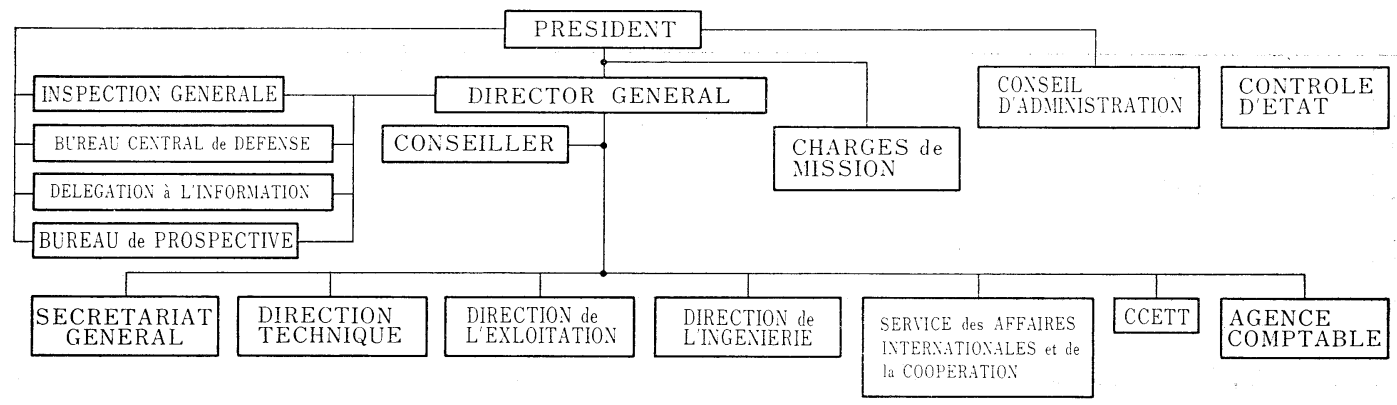

図 2 T.D.F の組織図

France-Inter, France-Culture, France-Musique, および France-Inter-Paris の FM 4 波を送信機 252 台で送出

その他 Radio-France Internationale : 短波放送を 20 台の短波送信機で，59 波 21 の方向に，1日延時間 274 時間, 5 言語（フランス，ドイッ，スペイン，ポルトガ ル，英語）を使って放送している.

（2）テレビ放送網（3 系統: TF 1, A 2, FR 3)

基幹放送所送信機 308 台

中継放送機 4,600 台

TF 1 は走查線 819 本方式（白黒）と, 625 本方式 (力

*イラン,イラク, サウジアラビアは SECAM-H 方式である.
ラー）の 2 種類があり，後者の放送網は完成間近で, 819 本方式は, 1981 年 5 月末で廃止となる予定である. A 2 およびFR 3 はカラーで UHF 带を使用している. 基幹局は $50 \mathrm{~kW}, 20 \mathrm{~kW}$ 級の送信機老多数使用し, 送 信所の自動化は 1970〜73 年頃にわたって行われ，集中 監視方式が採用された。最近，フランスのSECAM方式 は若干方式変更が行われることになり,従来のSECAM$\mathrm{V}$ 方式加ら SECAM-H 方式湾更され，受像機も，V 方式のあのは昨年いっぱいで販売を禁止された（ライン 切換信号を垂直から水平の帰線消去期間のバックポーチ に挿入する方法に切替える).

(3) 衛星中継 
表 1 フランス放送の組織

\begin{tabular}{|c|c|c|c|c|c|}
\hline & 事 業 体 & 人 員 & 主＼cjkstart要＼cjkstart業 & 財 & 備 \\
\hline 国 & $\begin{array}{l}\text { T.D.F } \\
\text { Télédiffusion de France } \\
\text { 送信担当公社 }\end{array}$ & $\begin{array}{c}3,181 \\
(3,600)\end{array}$ & $\begin{array}{l}\text { (1) ラジオ, FM, テレビ回線の送 } \\
\text { 信担当 ( } 2 \text { 衛星地球局を含む) } \\
\text { (2) } 6 \supset \text { 子会社 } \\
\text { (3) PTT と共有の研究所運営 } \\
\text { (C. C. E. T. T) }\end{array}$ & $\begin{array}{l}\text { 受信料の一部执よび } \\
\text { 送信施設賃貸料 }\end{array}$ & $\begin{array}{l}\text { 海外放送を含む } \\
\text { 10, rue d'Oradour-sur- } \\
\text { Glane-75015, Paris }\end{array}$ \\
\hline 立 & $\begin{array}{l}\text { INA } \\
\text { Institut National de } \\
\text { l'audiovisuel }\end{array}$ & 1,000 & $\begin{array}{l}\text { (1) ライブラリー管理 } \\
\text { (2) 専門研修 (職員) } \\
\text { (3) 視徳覚メディア研究 } \\
\text { (4) 将来の予測研究 } \\
\text { (5) 番組新方式の開発 }\end{array}$ & 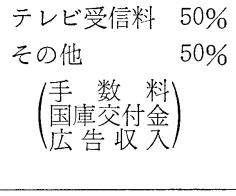 & $\begin{array}{l}\text { 7,000 時間の番組を提供した } \\
\text { 4, avenue de l'Europe } \\
\text { 94630, Bry-sur-Marne }\end{array}$ \\
\hline 機 & $\begin{array}{l}\text { TF } 1 \\
\text { Société nationale } \\
\text { télévision francaise } 1\end{array}$ & 1,250 & $\begin{array}{l}\text { テレビ番組（一般総合番組）の放 } \\
\text { 送 }(4,000 \text { 洔間/年) }\end{array}$ & 受信 料+広告収入 & $\begin{array}{l}\text { 15, rue Cognacq-Jay } 75340 \\
\text { Paris }\end{array}$ \\
\hline & $\begin{array}{l}\text { A } 2 \mathrm{~F} \\
\text { Anteme } 2 \text { France }\end{array}$ & 1,100 & 同上 $(4,000$ 時間/年) & 上 & $\begin{array}{l}5-7, \text { rue de Montessuy } \\
75341, \text { Paris }\end{array}$ \\
\hline 有 & $\begin{array}{l}\text { FR } 3 \\
\text { Société nationale de } \\
\text { programme france } \\
\text { regions } 3\end{array}$ & 3,500 & テレビ番組の放送 & 受 信 料 & $\begin{array}{l}\text { 5, avenue du Recteur- } \\
\text { Poincaré } 75016 \text {, Paris }\end{array}$ \\
\hline 業 & $\begin{array}{l}\text { Radio France } \\
\text { Société nationale de } \\
\text { radiodiffusion Radio } \\
\text { France }\end{array}$ & 2,200 & $\begin{array}{l}4 \text { 系統のラジオ番組の放送 } \\
\text { France-Inter } \\
\text { France-Culture } \\
\text { France-Musique } \\
\text { FIP } \\
\text { 海外放送 }\end{array}$ & 受 信 料 & $\begin{array}{l}\text { Maison de radio france } \\
116 \text {, avenue du President- } \\
\text { Kennedy }\end{array}$ \\
\hline $\begin{array}{l}\text { 有 } \\
\text { 限 } \\
\text { 会 } \\
\text { 社 }\end{array}$ & $\begin{array}{l}\text { S.F.P } \\
\text { Société francaise de } \\
\text { production et de créa- } \\
\text { tion audiovisuelles }\end{array}$ & 2,000 & $\left(\begin{array}{l}\text { 年間 } 2,000 \text { 時間の大型番組の制 } \\
\text { 㤰 } \\
25 \text { 本の映画番組販売 }\end{array}\right)$ & 番組販売収入 & 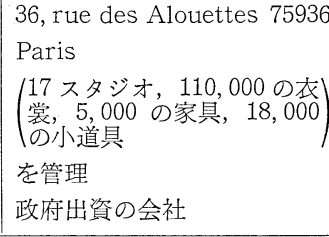 \\
\hline
\end{tabular}

INTELSAT, MOLNYA, および SYNPHONIE に送 受信するための地球局を Pleumeur-Bodou と Bercenayen-Othe の 2 カ所にもっている.

(4) 関連会社

次の 8 つの子会社をもっている.

(a ) S.O.F.R.A.T.E.V : 海外技術協力

(b) A.D.E.T.E ：サウジアラビアテレビ放 送網拡充

(c) S. A.R : ローカルコミュニティー への技術，資金協力

（d） S.O.M.E.R.A：中近東地域におけるラジ 才放送

(e) S.F.T : CATV

（f） G.I.R.A.T.E.V：ラジオおよびテレビ放送 協会のためのデータ処理 （g） S.A.T.E.L Conceil：衛星技術

(h) T.D.I : Télédiffusion Internationale

また, CNET (電気通信研究所) と共に CCETT (Centre Commun d'Etudes de Télévision et Télécommunications) を設立した. (後述)

参考として，フランスの放送技術部門の 1976 年に掠 ける活動区分を図了に示す．との図加ら海外技術協力部 門が 35\% 以上を占めていることがわかる. しかも，そ の主なものは, サウジ:フラビア，アフリカ，その他で, 政界，工業界が一体となって国策として協力しているの がわかる (図1参照). 主な国として，ナイジェリア， アブダビ, イラン, パキスタン, シリア, マダガスカ ル, ザイール, サウジアラビア, チュニジア, ソビエ ト，イラクなどがあり，1976 年度だけでむ， 20 カ国に 

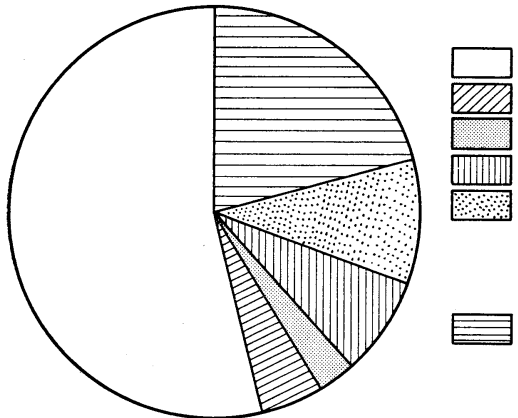

図 31976 年に拉ける技術活動の区分

ネットワークの建設

番組制作会社のプロジェクト

改善変更工事

アフリカ地域の協力

国際間技術協力

(サウジアラビア以外の国， SOFRATEV 担当)

国際間技術協力

(サウジアラビア SOFRATEV 担当)

及ふ心。

TDF の技術規格上，新しいむのとして, Eye-pattern の規格がある。図 4 ，図 5 および表 2 にその詳細を示 す. Antiopeの発表とともに，波形伝送技術の見なおし が行われているわけで，遅延等化の他に，直交分補償も 必要となってくると思われる。(筆者私見)

\subsection{S. E.P (Société Francaise de Production et} du Création Audiovisuelles)

大型番組制作部門を分離して設立した政拊出資の有限 会社で 17 のスタジオ，11 万着の衣裳， 5,000 亿及ぶ家 具， 18,000 の小道具類を所有し，番組を制作販売する. 最近，財政危機に直面し，人員削減のため職員約 1,000 名を解雇した. なお゙, フランスのテレビ番組の輸入番組 は55\% 程度にあなるという，政府はこれを $50 \%$ となる よう行政指導している。 また，客席 1,000 を持つ多目的 センター，ビデオラボラトリー，ヘリコプター中継設備 などを持っている他，Bry-sur-Marne に8つのスタジオ を持ったフィルム制作センターを作った (1975 年). こ れは 45 の編集室をむつ大規模なむのであり，3つの建 物から成っているが， ENG の将来の発展を見謂った感 がある。

\subsection{INA (Institut National de l'Audiovisuel)}

視聴覚研究所は，旧 ORTF の資料を継承し，これを 管理し提供する他, 内外研修生の教育訓練を行う。この 他, 視聴覚メディアの研究, 番組制作上の新機軸を生み 出すための独自の番組作成を行い，新しいタレントを送 り出したりする. 一方， 7,000 時間以上の番組を有料む しくは無料で国内抢よび海外に提供している。また，コ ンピューターアニメーションの技術研究むINA で行わ れていて，[Psyche-Anim 2] の名称のもとに，使用さ れている(TF 1, A 2 F, FR 3 は表 1 参照).

1.4 CCETT Centre Commun d'Etudes de Télévision et Télécommunications

ORTFの解体と再編成に際し, PTT (CNET) と TDF

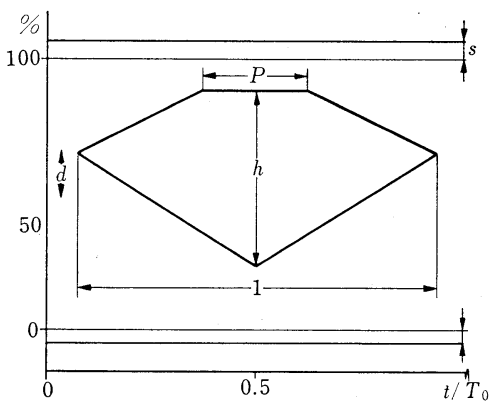

図 4 アイパターンの標準規格

$t$ (ns)

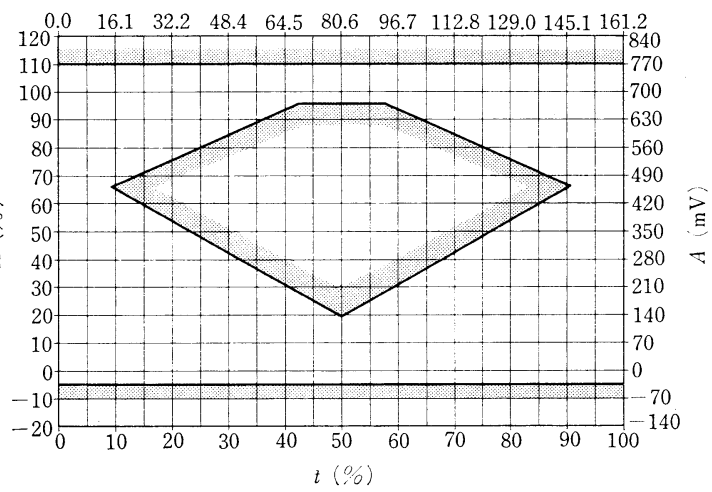

図 5 アイパターン用测定目盛

表 2 アイパターン規格（映像送信機出力音声ノッチなし）

\begin{tabular}{c|c}
\hline テーブル & アイパターンパラメーター \\
\hline アイ ハ イ ト & $h \geqslant 75 \%$ \\
オーバーシュート & $s \leqslant 10 \%$ \\
アンダーシュート & $i \leqslant 5 \%$ \\
アイの 位置ずれ & $d=16 \pm 5 \%$ \\
アイ の 幅 & $l \geqslant 80 \%$ \\
水 平 部 の 幅 & $p \geqslant 15 \%$ \\
\hline
\end{tabular}

が 2:1 の割合で研究者を出し設立した研究所である. その研究活動は,

（1）技術的基本事項の研究之調査 音声，映像信 号の調査分析, 統計, 符号化処理, 光学的記録再 生，および画質向上対策

（2）システムの実用化映像音声信号伝送問題, 映像システム，ファクシミリ，テレテキスト方式, ディジタルテレビ

（3）伝送回線網計画 コンピューター利用による 回線網接続の地域的構成と最適化，計算機間の高速 信号伝送

等と広範囲にわたり, 予算は PTT, TDF が折半してい る. 有名な Antiope はこの研究所でイギリスの Ceefax を改良考案したものである(写真 1 ).

(5) 697 


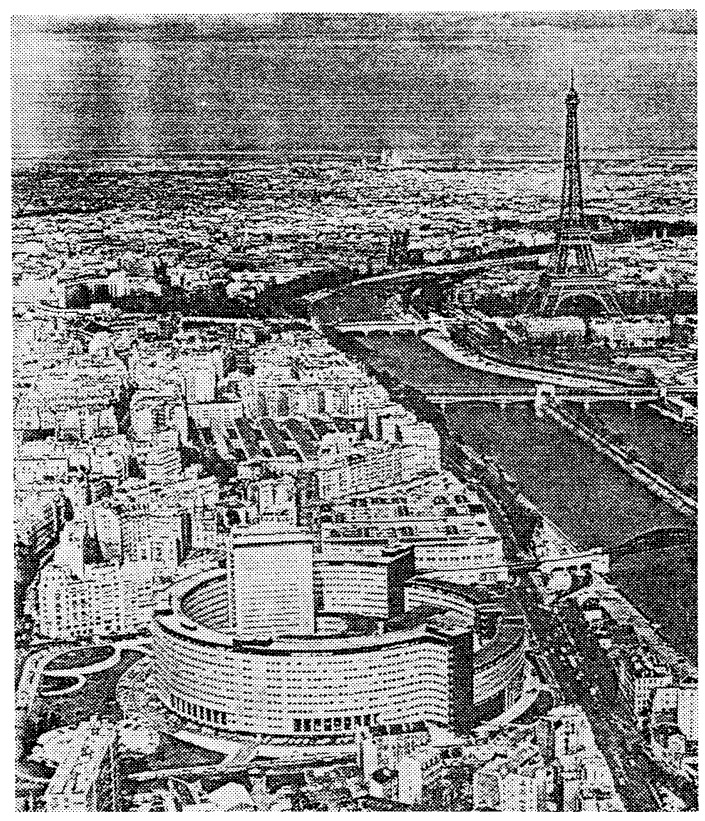

写真 1 エッフェル塔と Maison de Radio France

\subsection{SOFRATEV（海外コンサルタント）}

1973 年設立の有限会社で資本金は 145 万フランであ る. その主な業務は，送信所や回線網の設計，拡充，ラ ジオ,テレビおよびフィルム映画番組制作センター, 訓 練センタ一等の設計建設業務, 契約業務の協力, 工事実 施の監督, 製作工場での受取検査立合い, 工事監理等で あり，活動分野は先進国を除く世界各国にまたがってい る. 大統領を先頭にサウジアラビア, イラク, イラン等 の産油国の放送施設を SECAM 方式の採用に踏み切ら せた戦略的な動き，そして Antiope 方式の宣伝のため， アメリカで 1978〜9 年にかけ 8 回のデモンストレーショ ンを行い，その他，モスコー，ベルリン，モントルー，

THE NEW ORGANIZATION OF SVERIGES RADIO AS OF JULY 1,1979

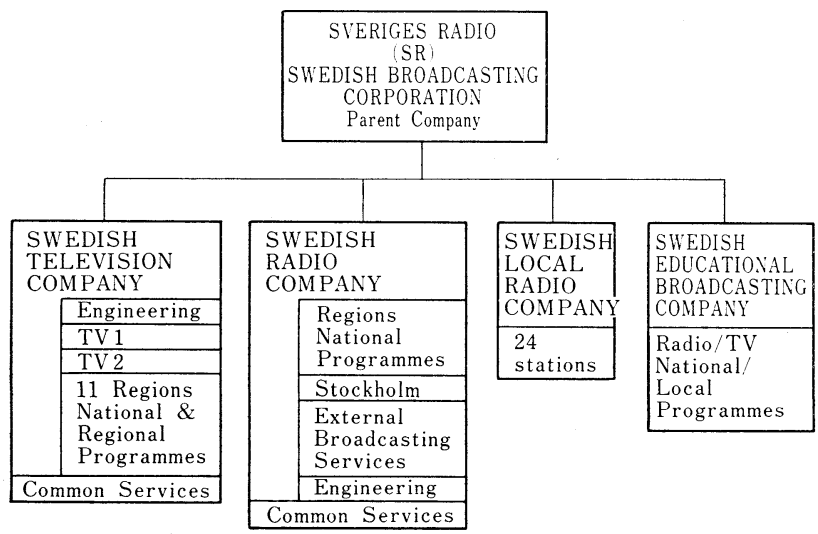

図 6・スウェーデン放送協会組織図

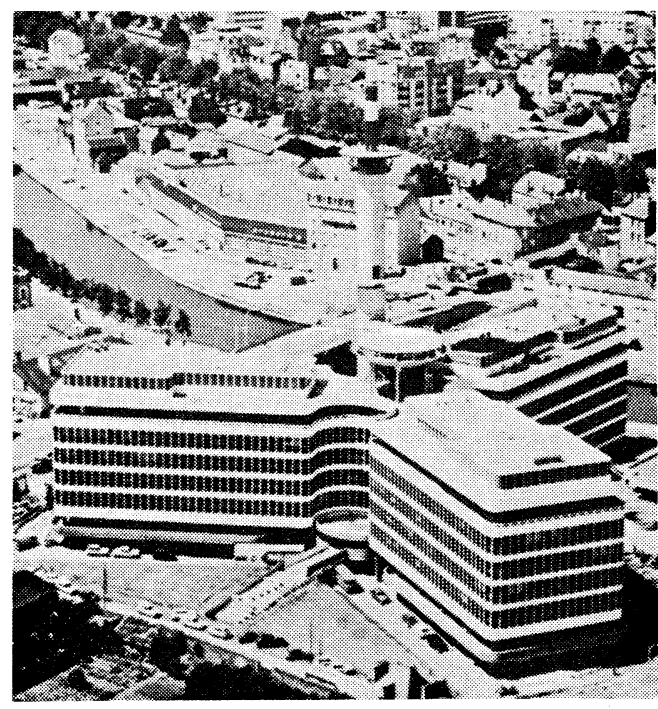

写真 2 CCETT

ボゴタブエノスアイレス, リスボン，アビジャン（象 牙海岸）など各地で，SOFRATEV が主体となって実演 を行うなど，その海外への PR 活動はきわめて活発で ある。

\section{6 その他}

フランスに㧍ける CATVは，ポンピドーの時代には 前向きに発展するような政策をすすめたが，ジスカール デスタン時代となってブレーキをかけるようになった. 現在, 20 カ所程度の共同アンテナ施設があるが, 外国電 波の再送信は許可されていない.

フランスの放送衛星は当初ドイッとの協力の下に進め られていたが，独自の衛星打上げを計画していて，1982 年には 2 チャンネルをフランス政府管理下に，1 チャン ネルをコマーシャル放送として利用するだろうといわれ ている.

また, フランスのテレビ送信方式は, 正変 調方式であり，かつ音声変調方式は振幅変調 を採用しているため, 非線形回路を通ると映 像信号から音声への漏話が生ずる。そのため 中継放送機などでは $S / N$ の劣化が他方式と 比較して多いといわれる.

\section{2. スウェーデン放送協会} (Sveriges Radio Ab-S. R.)

\section{1 概 要}

スウェーデン放送協会は北欧の放送機関の 中で中心的な存在である. 1978 年 5 月の国会 の決議により昨年 1 月に組織改正が行われ, 図6に示すように, SR の傘下にテレビ, ラ 


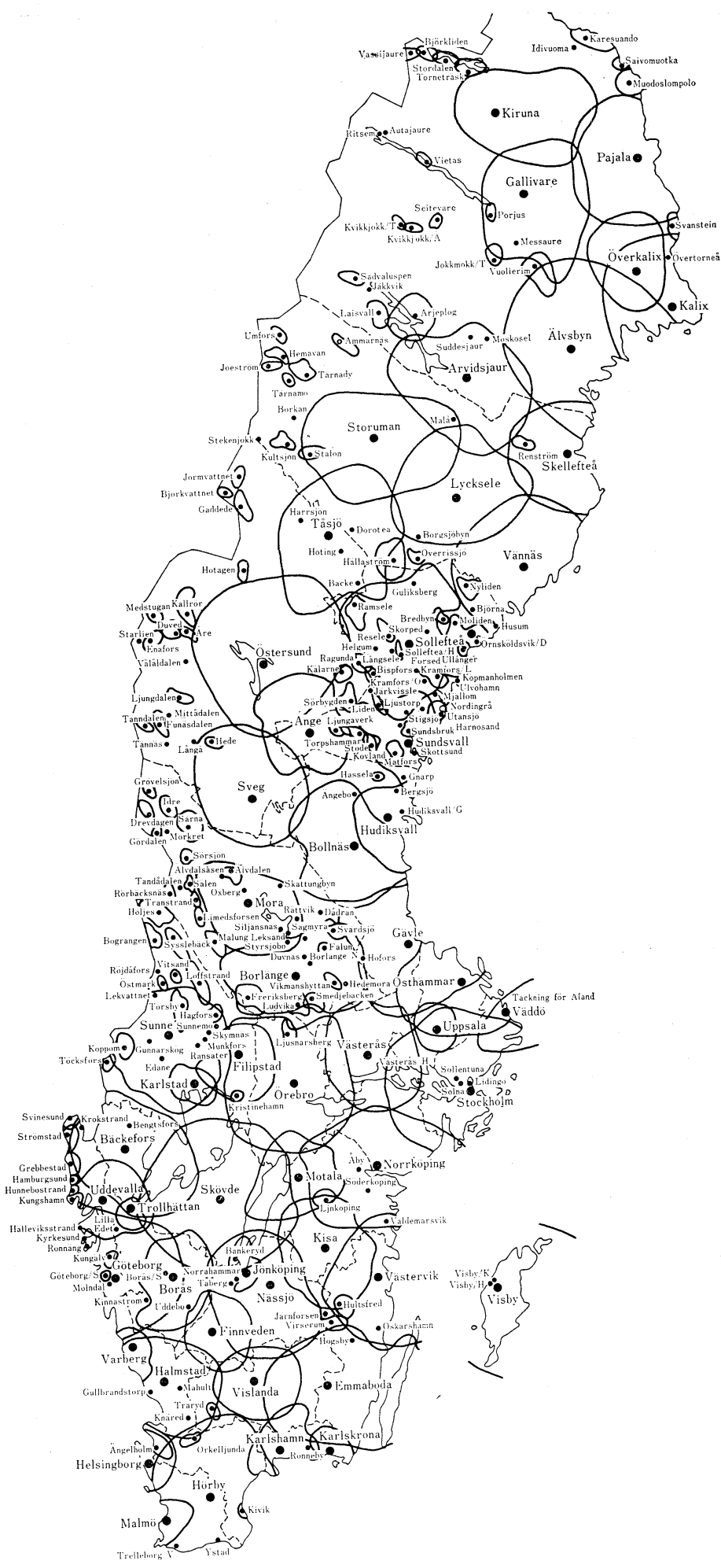

図 7 TV-1 のサービスエリア
ジオ，ローカルラジオ，および教育 放送の 4 系統の番組制作会社を設立 した，送信設備および中継回線の運 用管理は電通省が行っているため, 番組制作がその主な業務である.

$\mathrm{SR}$ は，主として長期計画，資金 計画など傘下会社の全般的な総括を 行っている. しかし番組そのむのに ついては関与していない，傘下の各 放送会社は，ラジオ，テレビ番組作 成については全面的に任されてい る.

テレビ部門の SVT は, TV-1, TV-2，扔よび，11のローカル番組 と，テレビ技術部門で構成されてい る.

ラジオ部門は, 番組制作, シンフ オニー，オーケストラ，ラジオ技術 部門，全国放送番組，および海外放 送部門で構成されている. この他， ローカルラジオ部門および教育放送 部門の会社があり，業務分担をして いる. 全体の職員は 5,800 人であ る.

\section{2 放送番組, 放送網}

放送はテレビ 2 系統, FM 3 系統 (首都は 6 系統), ラジオ 1 系統の番 組を送出している他，海外放送を英 語, ドイッ語, フランス語, スペイ ン語，ポルトガル語，ロシア語，ス ウェーデン語の 7 カ国語で送出して いる。

テレビ抢よび FM 放送の人口カ バレージは 99\% に達し, 図 7 の TV-1 のサービスエリア図のとお り，放送網は完成している．テレビ の基幹局は 53 局で，その中 3 局だ けは有人運用している.

FM 放送は第 3 チャンネルを用 い，全国的な公衆情報サービス (Public Information一PI) を行っ ている. スウェーデンは電話の普及 あ米国に次ぎ，乙の補完としてPI システムを使い，全国にわたりサー ビス可能なポケットベルサービス， 番組表示, テキストの送出などを行 


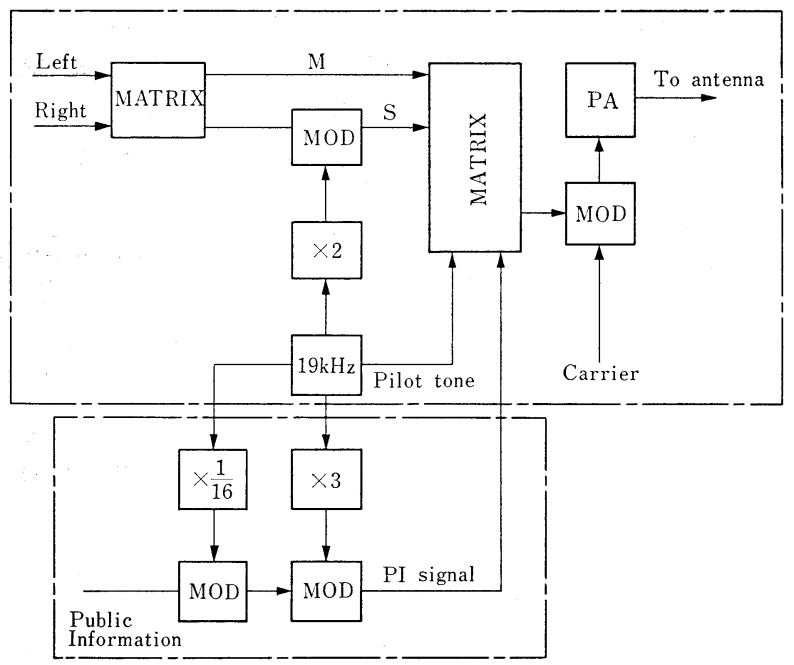

図 8 PI 送信機系統図

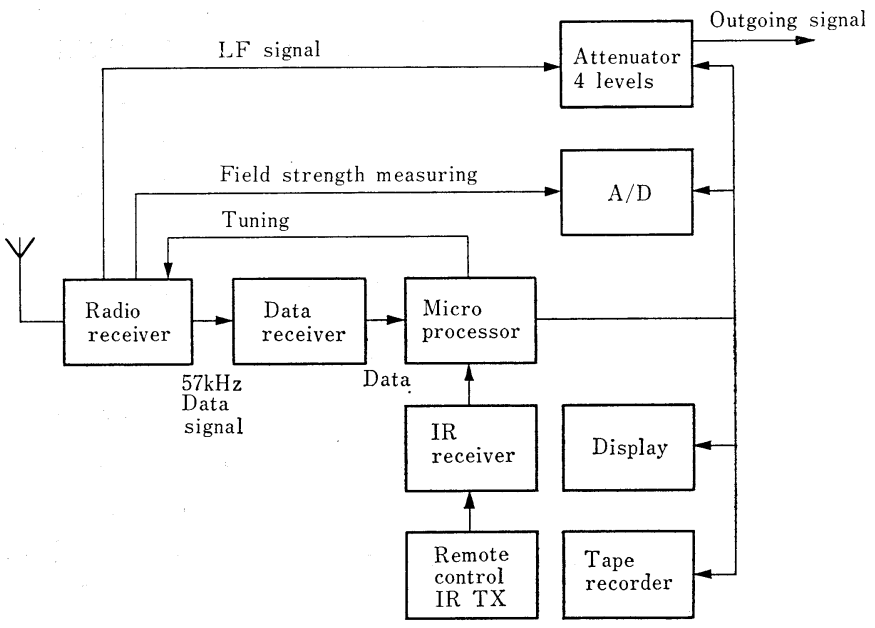

図 9 PI 受信機系統図

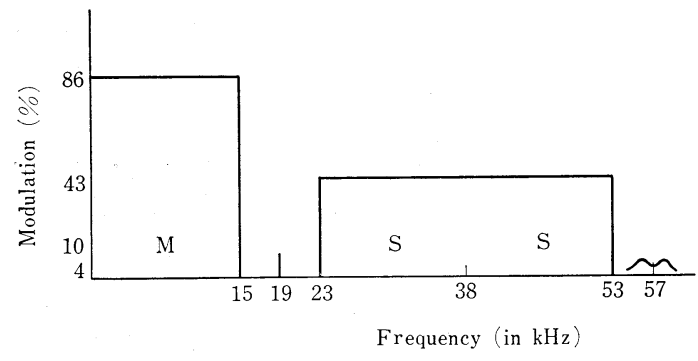

図 $10 \mathrm{PI}$ サービスのスペクトラム

っている. 図 8 にPI システムの送信機系統, 図 9 亿PI 受信機の系統図を示す。図 10 はPI システムを重畳し た FM ベースバンド信号のスペクトラムを示す. PI 情 報で $19 \mathrm{kHz} / 16=1,187.5 \mathrm{~Hz}$ の短形波を位相変調させ, その信号で $57 \mathrm{kHz}$ の副搬送波を周波数変調（土3 kHz
偏移）して既存の FM ステレオベース バンド信号に重畳する方法である. 受信 機は，自動同調機能をむたせていて，氻 なり高級な回路となっている.

短波放送は 3 台の $500 \mathrm{~kW}$ 送信機で行 っており, 空中線は対数周期アンテナ (利得 $12 \mathrm{~dB}$, ビーム幅 $60^{\circ}$ ) を使用し ている。また，ての他に $100 \mathrm{~kW}$ の短波 送信機でSSB 放送を行っている. 短波 の SSB 放送は，スイスフフィンランド でむ実験的に実施されたことがあるが， 現在は中止している.

\section{3 施 設}

$\mathrm{SR}$ の傘下の各会社の建物はストック ホルム市内の 12 カ所以分散している が，主要な建物であるラジオおよびテレ ビセンターは, 図11の(1) Oxenstierns gatan にある. 第 2 テレビの事務棟の建 替えは労組の反対のため 5 年以上にわた り宙に浮いた形となり，着工されていな い.

スタジオの設備は, カメラは主として フィリップス製 LDK-3 が主として使わ れ, VTR は Ampex, フィルムカメラ は Rank Cintel 製が主として使わ机て いる.

コンピューターアニメーション技術 は，スウェーデンの技術者が調查した範 囲では，彼らのものが世界で一番進んだ あのだといっている．新技術に対する取 組みは，きわめて積極的で，技師長，副 技師長が世界中のメーカーを訪問し，新 技術の趨勢の把握に努めるなどの他，北欧諸国の放送技 術の中心となり, 技術仕様の共通利用, 衛星に対する考 え方をまとめるなど，多くの点で活躍が目立つ. 衛星放 送は, 北欧諸国の言語の共通性を考慮し, 音声屯多重化 をはかるため，ステレオ1チャンネルに数個のコメンタ リーチャンネルを使う案が出されている.

\section{4 その他}

受信料収入は，SR，テレコム，打よび公共建築監理機 構の 3 者に, 放送業務運営経費として分けられる。

教育放送の必要経費は，受信料でなく税収入から支出 される．なお，SR の必要経費は物価指数に比例して増 額されることになっているが，実情は必ずしもそうでな いという.

スウェーデンの CATV は, 自主番組の送出は許され 

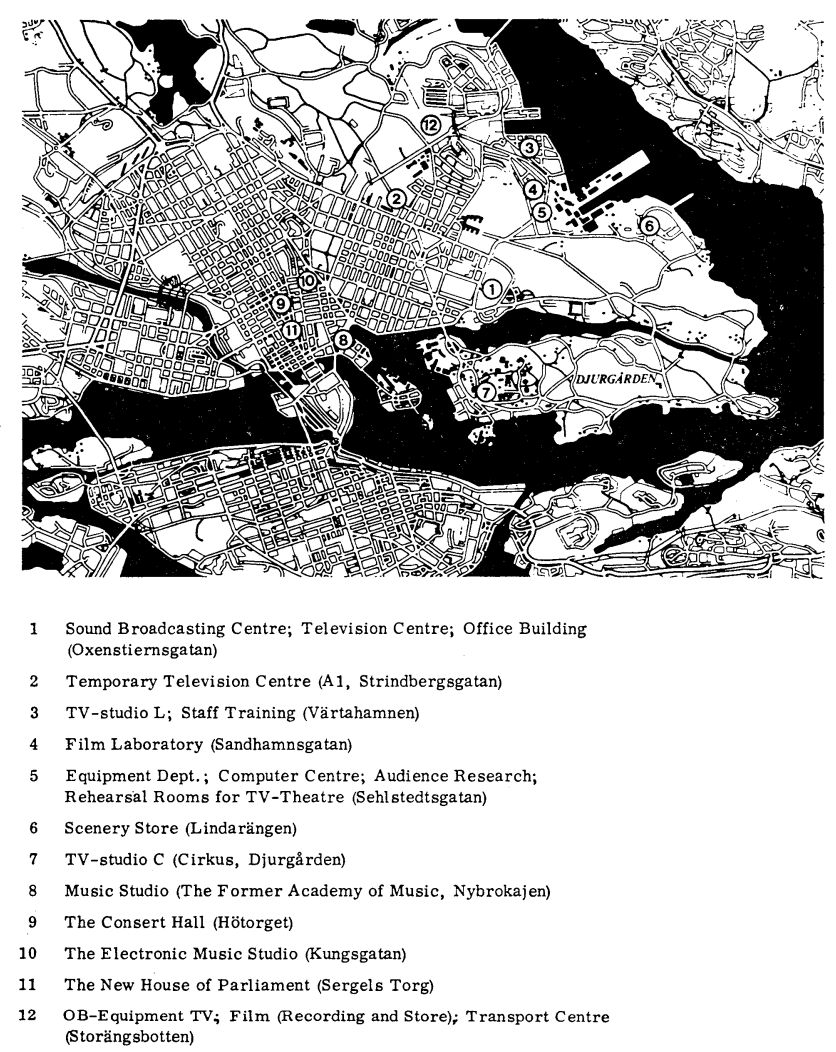

図 11 放送会社の建物の散在

ず外国の放送の再送信む政府の許可が必要である．加入 者は全家庭の $40 \%$ 以上に及ぶと報告されている。

テレテキストは英国方式を踏襲し, 実験放送を続けて いる.

な扔，技術研究はスウェーデン電気通信無線研究所で 主として行われて抢り，表了のような構成となっている が，人数は 50 名程度の規模のむのである.

(昭和 55 年 4 月 25 日受付)

\section{〔参 考 文 献〕}

1) フランス国営放送: フランス国営放送の組織

(1) C. E. White: Progress in French Telecommunications, Services, Telecommunicatins 3 (1980)

3) F. Coupigny: La fabrication assistée par ordinateur de dessins a l'aide du Systémes "Psyche-Anim2" Radiodiffusion (1979)

4）スエーデン放送協会: Sveriges Radio

5）スエーデン放送協会: Sveriges Television AB
表 3 スウェーデン電気通信研究所の組織

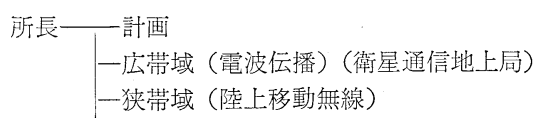
レビチャンネルを用いたデータ伝送, 衛星放送)

一機器テスト（機器の電波妨害テスト） (無線機器の認可) (誠作機器のテスト) （広帯域，狭帯域部門への協力） 